\title{
Industrial relations reform, firm-level bargaining and nominal wage floors
}

\author{
Nicholas Giannakopoulos ${ }^{\mathrm{a}}$ and Ioannis Laliotis*
}

\begin{abstract}
We investigate the impact of the 2011 industrial relations reform in Greece that made firms with less than 50 employees eligible to participate to firm-level bargaining. Matching administrative contractual data with longitudinal firm-level data we identify firms affected and not affected by the reform. We find that during the first post-reform year, affected firms with less than 50 employees experienced a 4.8 percent increase in the probability of firm-level contracting and a 12 percent drop in wage floors relative to not affected firms. We also report estimates regarding the post-reform employment effect of firm-level bargaining.
\end{abstract}

JEL codes: J31; J41; J52

Keywords: Firm-level bargaining; Wages; Reform; Greece

\footnotetext{
* Corresponding author: London School of Economics and Political Science, European Institute, e-mail: i.laliotis@1se.ac.uk, Tel: (+44) 2079556790.

${ }^{\mathrm{b}}$ University of Patras, Department of Economics, e-mail: ngias@upatras.gr, Tel: (+30) 2610969843. We would like to thank the Editor, Matias Cortes and three anonymous referees for providing feedback on our original manuscript. Useful comments on earlier stages of our work have been kindly provided by Efi Adamopoulou, Pedro Martins, Pascalis Raimondos-Møller, Jan Švejnar and participants at the 26th European Association of Labour Economists Conference, the 29th European Economic Association Annual Congress and the 5th International Meeting on Applied Economics and Finance. The usual disclaimer applies.
} 


\section{Introduction}

Decentralised collective bargaining is a commonly used mechanism for setting wage floors that reflect workplace characteristics, productivity and market idiosyncrasies (Card and de la Rica, 2006; Le Bihan et al., 2012; Breda, 2015; Fougère et al. 2018). This mechanism has been found to be popular during recessionary periods because it facilitates nominal downward wage adjustments (Daouli et al. 2016; Addison et al. 2017; Janssen, 2017). However, apart from market and firm-specific attributes, the probability of a firm to engage in decentralised collective wage negotiations is also affected by the provisions of the existing industrial relations laws applied to a specific country (Dustmann et al. 2014; Lucifora and Origo, 2015). Hence, restructuring the industrial relations framework may alter the motives and characteristics of the agents participating to wage floor negotiations. Eventually this is expected to alter the structure of firm-level contracting, the determinants of contractual nominal wage floors and affect employment as well (Katz, 1993; Jimeno and Thomas, 2013; de Pinto, 2017; Brändle and Goerke, 2018).

In this paper we study the decentralised bargaining system in Greece by investigating the 2011 industrial relations reform that allowed firms with less than 50 employees to participate to firm-level bargaining. The reform (Law 4024/2011, implemented in October 2011) aimed at confronting the longstanding wage rigidities and align labour costs with firmspecific characteristics and labour market conditions. For analytical purposes, we collected the universe of administrative contractual data for the period 2006-2016 and matched them to longitudinal firm-level data in order to identify firms that were affected and not affected by the reform on the basis of their number of employees. A difference-in-differences estimation strategy shows that during the first twelve months after the reform, firms with less than 50 employees experienced a 4.8 percent increase in firm-level bargaining compared to firms with 
more than 50 employees. During that period (November 2011-December 2012) the number of firm-level agreements quadrupled compared to pre-reform years. However, that rise was shortlived. Firm-level negotiations became less popular amongst labour unions and policy makers in later years as they were mostly leading to downward nominal wage adjustments (Daouli at al. 2016). Nevertheless, recent empirical evidence suggests that since 2012 the allocation of labour across firms improved drastically because more productive firms were able to attract or retain more workers (Bulman and Pisu, 2018). In this paper, we attempt to provide empirical evidence on labour market effects of the 2011 industrial relations reform using longitudinal firm-level data. We estimate the impact of the reform on contractual wages by using firms that did not sign firm-level agreements as the counterfactual scenario and also report estimates regarding the post-reform effect of firm-level bargaining on employment.

Before the 2011 reform the Greek collective bargaining framework was governed by the provisions of Law 1876/1990. Representation of workers within a firm was possible either through a trade union (TU) or an association of persons (AP) as both types were officially recognised by earlier legislation (Law 1264/1982). TUs can be formed by a minimum of 20 workers and APs could be established by at least 10 workers but only in firms employing up to 40 workers and only in the absence of a TU covering already half the firm's workforce. Moreover, APs were short-lived as they could not be active for more than 6 months and they were formed for very specific purposes only. Furthermore, under the previous regime, decentralised collective agreements over wages and other employment conditions could only be signed in firms with TUs and given that they employ at least 50 workers. This institutional feature restricted a large part of the labour force from engaging in firm-level wage negotiations, as firms with less than 50 employees cover at least 60 percent of the total private sector workforce in Greece. The 2011 reform (Law 4024/2011) removed the restrictions regarding the ability of APs to sign firm-level collective agreements. More specifically, it eliminated the 
size threshold according to which APs could only operate in firms with less than 40 workers. Therefore, it allowed the formation of APs regardless of the firm size, given that the AP represents at least 60 percent of the total workforce and that there is not a TU already within the firm. In addition, the reform allowed APs to operate on a permanent basis instead for 6 months only. Hence, the 2011 reform made all firms eligible to participate to decentralised wage negotiations by removing the institutional threshold previously set to 50 workers. The only firm size restriction is that APs should be formed in firms with at least 5 employees in order to ensure that the 3 out of 5 employees are elected as workers' representatives.

In terms of negotiated wage outcomes, the 2011 reform redefined the limits within which wages floors can oscillate. Under the previous regime, employee remuneration was subject to different collective agreements (sectoral, occupational, firm-level) and the one with the most favourable provisions was applied, i.e. the "favourability principle". Moreover, firmlevel negotiations could not determine wage floors lower than those set at broader levels of collective bargaining, i.e. sectoral and occupational. However, after the reform firm-level collective agreements prevail relative to sectoral and occupational ones, but not relative to the National General Collective Agreement. Therefore, negotiations between employers and employees can lead to wage floors deviating either above or below thresholds set at the sectoral or occupational levels while the National Minimum Wage provisions are statutory and apply to all workers. Details for the transformation of the employment regulation in Greece is provided by Voskeritsian and Kornelakis (2014) and the role of APs under the 2011 reform is presented in Daouli et al. $(2013 ; 2016)$.

For analytical purposes we develop a unique dataset containing every official wage floor-setting agreement signed at the firm level in Greece during the period 2006-2016. This extends the data developed by Daouli et al. (2016) to investigate nominal wage adjustments in firm-level agreements during the period 2010-2013. The importance and superiority of contract 
data over survey data for analysing downward wage rigidities has been highlighted in several studies (e.g. Christofides and Stengos, 2003; Druant et al., 2012; Le Bihan et al., 2012). However, covering a longer period is not the only extension. Firm-level contractual data have been matched to demographic and balance sheet information not only for firms engaged in decentralised negotiations but also for those not setting their wages at the firm level. This allows the identification of any changes in firm behaviour before and after the reform regarding decentralised contracting and its outcomes. Despite an increasing public interest about the future of decentralised collective bargaining in Greece (van Ours et al. 2016) our knowledge about its changing structure due to the 2011 reform remains limited.

Our empirical strategy relies on identifying firms that were affected by the 2011 reform. The developed longitudinal dataset provides us with information on firm size. Firms affected by the reform employ 5-50 employees. Contractual wage floors for this group are compared with wage floors for firms employing more than 50 employees. Since we observe wage floors for both groups in the pre- and post-reform periods, we use differences-in-differences estimators to identify the differential impact of the reform on nominal contractual wages. We also estimate linear and non-linear probability models regarding the incidence of firm-level contracting using flexible model specifications and controlling for a wide set of characteristics. This allows us to identify whether affected and not affected firms exhibited a differentiated response in firm level bargaining after the 2011 reform. Contractual wage outcomes are modelled using OLS and models corrected for non-random sorting of firms into decentralised negotiations. Lastly, we report estimates regarding the differentiated impact of firm-level contracting on employment by estimating a treatment effects model for affected and nonaffected firms. Our results show that firm-level contracting varies with firm size, location, industry, market power and performance. Moreover, this heterogeneity became more apparent after the 2011 reform. Firms affected by the reform experienced a post-reform increase by 1.5 
percent in firm-level bargaining, compared to firms not affected. The result is stronger, 4.8 percent, during the first twelve post-reform months. In addition, affected firms face higher downward nominal wage floor adjustments, about 11-15 percent, compared to not affected firms. In robustness checks we restrict the estimation sample to narrower windows around the policy cutoff to ensure the validity of our estimates. Finally, firms signed firm-level contracts after the 2011 reform experienced an increase in employment.

Our paper contributes to the literature studying the determinants of firm-level contracting (Christofides and Stengos, 2003; Card and del la Rica, 2006; Avouyi-Dovi et al. 2013; Daouli, 2013; 2016) by examining how collective bargaining behaviour of firms changed due to the reformed provisions of the industrial relations framework. Moreover, our work is related to the literature of the determinants of negotiated wage floors set at broader levels of bargaining, i.e. industry-level wage floors (Fougère et al., 2018). In addition, the present study is linked to the literature investigating mechanisms of downward nominal wage adjustments during recessions, especially in southern European countries (Addison et al., 2017).

The remainder of this paper is structured as follows: Section 2 discusses the data. Section 3 outlines the empirical strategy and Section 4 presents and discusses the results. Section 5 concludes.

\section{Data}

In order to examine variation in contractual wage floors we collected information on decentralised bargaining outcomes from the universe of official firm-level contracts signed in Greece during the period 2006-2016. The dataset has been developed by extracting information from several sources, i.e. the printed registry (2002-2008) and the online registry (2010-2016) maintained by the Ministry of Labour, Social Security and Welfare (YPAKP) and the publicly 
available agreements on the Greek Organisation for Mediation and Arbitration (OMED) website, covering the period 2006-2016. In order to ensure that each contract is a unique entry in our dataset we matched all contracts using their signing date and company name. Wage floor provisions were only available for the period 2006-2016, hence contracts signed during 20022005 were excluded. During the period 2006-2016 there were 3,364 contracts containing information on business name, location of the agreement, signing and effective dates and $85 \%$ of them include wage floor provisions. Using the tax identification number and the company name referred in each contract we matched them to firms included in the ICAP Data.Prisma dataset that covers all firms in Greece and provide information on their basic characteristics, balance sheet data, contact details etc. Information on the tax identification number was not available for 220 contracts ( $5.6 \%$ of the original sample).

This exercise resulted in a rich longitudinal firm-level dataset following firms that do and do not participate to firm-level bargaining before and after the 2011 reform. Moreover, we have information on their number of employees, legal status, sector of economic activity (NACE Rev.2, 4-digit) and location (NUTS-3). Firms are classified into affected and nonaffected ones, based on their average number of employees during the pre-reform period (20062011). For contracts without information on the tax identification number we uncovered their number of employees by contacting them directly using details included in the official contract (along with information on legal status, sector and location). Thus, our dataset consists of monthly observations (January 2006-December 2016) of firms with non-missing information on firm-size, legal status, sector of economic activity and location. For firms that signed firmlevel contracts we also collected information regarding their employees' representation type, i.e. TUs, APs or local trade unions.

Figure 1 compares the evolution of firm-level contacting for firms affected and not affected by the reform. Firm-level bargaining increased for a few months after the reform for 
firms with 5-50 employees. We also observe a spike 16 months before the reform for affected firms, but this refers to contracts signed by local trade unions and mainly corresponds to a specific industry, i.e. shipyards located at Piraeus port. The timing of firm-level contracting has also changed. Before the reform most contracts were signed one month after the National General Collective Agreement but during the post-reform period they tend to be signed earlier in the year (Figure 2).

[Figure 1 about here]

[Figure 2 about here]

For firms that signed firm-level contracts we observe their contractual nominal wage floors as those are reported in the document of each agreement and use them as our main wage adjustment measure. We also observe wage floor changes in those contracts and use them as an additional indicator. Figure 3 (4) compares wage floor levels (changes) for affected and not affected firms 12 months before and after the reform. Wage floor reductions for the former were greater as compared to the latter shortly after the reform (6 months) with that difference remaining stable afterwards. Furthermore, pre-reform bargained wage outcomes seem to follow parallel trends over time.

[Figure 3 about here]

[Figure 4 about here]

Regarding the sources of firm-specific heterogeneity, we should notice that the available balance sheet information is limited. Missing information on many firms restricts us from constructing firm-specific performance indicators. For instance, it is well established that including controls for market concentration and rent payments may explain a large part of contractual wage variation (Guertzgen, 2009; Breda 2015). In order to overcome such limitations, we estimated three indicators by sector and year to be used in robustness checks. 
The first one relates to worker productivity. It is constructed by regressing (ln) hourly wage rates of the 2-digit NACE Rev.2 sector (Labour Force Survey, CPI: 2015=100) on age, years of education, gender and regional fixed effects. The second one captures profitability differences between sectors, and it refers to the estimated average profitability by year and sector (NACE Rev.2, 4-digit, ICAP, CPI: 2015=100). It is constructed by regressing the ratio of operating income net of depreciation over total assets on total assets, firm's age, the Herfindahl-Hirschman Index and year dummies (Grullon et al., 2017). The third index is the estimated price cost margin by year and sector (NACE Rev.2, 4-digit, ICAP, CPI: 2015=100) in order to account for industry concentration levels. We follow Aghion et al. (2005) and we define price cost margin as the operating income before depreciation minus depreciation scaled by total sales. We also use a variable indicating whether a sectoral agreement (at NACE Rev.2, 4-digit) is signed in each month in order to control for synchronization effects in the collective bargaining process. Lastly, in order to control for prevailing local labour market conditions, we include the monthly regional unemployment rate and its annual growth (provided by EL.STAT.).

For the basic variables used in our empirical analysis, Table 1 presents descriptive statistics calculated by period and group of firms. The incidence of firm-level contracting has increased significantly in the post-reform period for both treated and non-treated firms, although the increase is larger for the former. Bargained wage outcomes have deteriorated for all firms, however, reductions for affected firms are more pronounced after the reform. Firm size, ownership status (private firm or not), industry affiliation and geographical location, seem to be sufficiently balanced between periods and groups of firms. Some of the reported variables vary at more aggregate levels, e.g. sector or region, so flexible model specifications with fixed effects will be used to capture this type of heterogeneity before and after the implementation of the reform. 
[Table 1 about here]

\section{Empirical Strategy}

We apply a difference-in-differences empirical design in order to examine any differential effects on the probability of firm-level contracting as well as on labour market outcomes caused by the 2011 industrial relations reform. Law 4024/2011 made firms employing less than 50 workers eligible to engage in decentralised collective negotiations, as long as their employees are represented by either a trade union (TU) or an association of persons (AP) during the negotiation process. Therefore, we compare bargaining outcomes for firms employing less than 50 employees, i.e. those now allowed to participate to decentralised negotiations, to firms employing more than 50 employees, i.e. those not affected by the elimination of the size threshold. Our main identifying assumption is that in the absence of the 2011 reform nominal base wages would have evolved in a similar way for firms belonging to both groups (as shown in Figures 3 and 4).

In this paper, the probability of a firm-level collective agreement and bargained nominal base wage outcomes are modelled as follows:

$\mathrm{y}_{\mathrm{ijmt}}=\alpha_{\mathrm{jt}}+\beta_{\mathrm{tm}}+\theta\left[\right.$ Post $_{\mathrm{t}} \times \mathbf{1}\left(\right.$ Treated $\left.\left._{\mathrm{i}}\right)\right]+\mathrm{u}_{\mathrm{ijmt}}$

where $y_{i j m t}$ denotes the incidence of a decentralised agreement in firm $i$, classified in industry $j$ at calendar month $\mathrm{m}$ of year $\mathrm{t}$, or its bargained nominal base wage outcome. Our models control for industry, time, region and firm-specific fixed effects as well for indicators capturing the prevailing economic conditions. Post $t_{t}$ is an indicator variable equal to one during the period after the implementation of the reform (November 2011) and $\mathbf{1}\left(\right.$ Treated $\left._{\mathrm{i}}\right)$ is switched on for firms employing less than 50 workers, hence not eligible for decentralised bargaining before 
the reform. Therefore, $\theta$ is the parameter of interest representing the differential impact of the reform on firm-level contracting and bargained nominal base wage outcomes.

Results on the incidence of firm-level contracting will be reported using both linear probability estimates and probit marginal effects. Results on bargained nominal base wage outcomes will be reported using both unadjusted OLS estimates and estimates adjusted for nonrandom selection of firms in decentralised negotiations. For the latter, we follow Le Bihan et al. (2012) and Fougère et al. (2018) and estimate probit models for engaging in firm-level bargaining, as in equation (1), augmented with dummy indicators regarding the workers' representation type within the firm, i.e. trade union or local trade union. According to these studies, variables related to either negotiation costs or legal constraints can be used as exclusion restrictions since they are assumed to affect only the timing of the bargaining process but neither the size nor the direction of wage floor adjustments.

\section{Results}

\subsection{Impact on firm-level contracting}

Table 2 displays difference-in-differences estimates regarding the impact of the reform on the probability of firm-level contracting. Linear probability estimates are reported in columns 1 to 3. The results suggest that in firms with 5-50 employees the probability of firm-level contracting increased by 0.10 percentage point per month (or 1.2 percentage points per year) relative to firms employing more than 50 workers, hence not affected by the reform. All estimates are statistically significant at the 1 percent level. Replacing year with month-ofagreement fixed effects (column 2) does not change the results in a meaningful manner. In

column 3, we interact firm size with industry fixed effects and additionally include industry- 
year interactions. The results still suggest a 0.10 percentage point increase in firm-level contracting for affected firms.

We contrast linear probability model estimates to probit marginal effects (Puhani, 2012) in columns 4-6. The estimated marginal effects are similar to the OLS coefficients. They suggest that the reform led to a 0.15 percentage point increase per month (or 1.8 percentage points annually) in the firm-level contracting probability for firms affected by the reform (550 employees) relative to firms with larger firm-size. The estimates are similar when we use industry-year interactions and month-of-agreement fixed effects (column 6) instead of year fixed effects (column 5).

[Table 2 about here]

\subsection{Impact on wage outcomes}

Table 3 provides difference-in-differences OLS estimates regarding the impact of the reform on nominal base wage outcomes (levels and changes) using alternative model specifications. All models are estimated on the sample of firms that signed firm-level contracts between January 2006 and December 2016. In the first three columns we use (ln) nominal wage floors as the dependent variable. Conditional on the adopted specification there was a postreform reduction in the range of 11-15 percent for firms employing less than 50 employees (columns 1-3). Without controlling for industry, size and year fixed effects the wage floor reduction is 15 percent, while after controlling for fixed effects and their interactions the estimated effect drops to 11 percent (column 3). Columns 4-6 report OLS estimates for models using bargained nominal wage floor changes as an outcome. The results point to the same conclusions, i.e. a reduction in bargained nominal wage changes around 8-10 percent, subject to the model specification, for firms affected by the reform. The reported difference-indifferences estimates do not simply pick up any pre-existing trends in bargained nominal base wage outcomes. As already shown in Figures 3 and 4, both wage measures followed parallel 
pre-reform patterns for all firms. After the reform, all firms experienced wage reductions although the mean reduction was larger for the group of firms that became eligible for decentralised bargaining.

\section{[Table 3 about here]}

The difference-in-difference estimates reported so far suggest that the 2011 reform had had a negative base wage impact on treated firms. However, as those results are conditional on the sample of firms that signed a wage contract in a specific month during the period under consideration, they could be biased from non-random selection of firms into decentralised negotiations. In order to account for such non-randomness, we adopt a Heckman correction approach. In the first step, we estimated a probit model corresponding to specifications 4-6 in Table 2 augmented with a binary variable indicating the workers' representation type within the firm, i.e. a trade union or a local trade union. This variable will be used as our exclusion restrictions that will allow for a proper model identification, as it has been shown to affect the bargaining process but not the outcomes (Le Bihan et al., 2012; Fougère et al., 2018). Table 4 displays the results. It seems that the unadjusted OLS estimates presented in Table 3 are not seriously biased. The difference-in-differences parameter estimates are similar and indicate that both bargained nominal post-reform wage floors and changes were reduced for the group of firms affected by the reform, relative to not affected ones. The inverse Mills ratio obtained from the decentralised bargaining participation equation is statistically significant at the 1 percent level indicating negative selection into this level of bargaining.

[Table 4 about here]

\subsection{Robustness checks}

After providing evidence that our parameters of interest are not driven by pre-policy trends and non-random selection, we test their robustness to the inclusion of additional 
covariates capturing firm-specific heterogeneity and prevailing market conditions. More specifically, we include location fixed effects (NUTS-2) and an ownership status (private or public) indicator. The prevailing labour market conditions are controlled for by the regional unemployment rate level and growth. Productivity differences across industries are captured by the sector-specific average hourly wage rate, profitability differences across sectors are approximated by a measure for the returns on assets, and industry concentration is measured by sector-specific price cost margins. A dummy indicator for whether a sectoral agreement has been signed during the same month is used in order to control for sectoral differences regarding the synchronisation of firm-level contracting with sectoral-level collective bargaining. Table 5 displays the results. The first column displays difference-in-differences results regarding the probability of firm-level contracting also controlling for the type of worker representation within the firm; this is our first stage regression used to account for non-random selection into decentralised negotiations when modelling bargained wage outcomes. The estimated difference-in-differences coefficient remains unchanged as compared to the one in Table 2. Moreover, it seems that private sector companies, those operating in sectors high hourly wages and higher price cost margins and those located in regions with higher unemployment are less likely to sign firm-level contracts. Yet, firm-level contracting is more likely in regions where the unemployment grew faster. The results for bargained wage changes regardless of accounting for selection are also robust to the inclusion of the above firm and market-specific covariates.

We also report estimates from estimating our model using a shorter time period around the 2011 reform (twelve months before and after). For firms that became eligible for decentralised negotiations it is more likely to participate to this sort of bargaining by 0.04 percent per month (or 4.8 percent per year) relative to firms not affected. The likelihood of participation is higher for firms with TUs or local TUs and when the local labour market 
conditions deteriorate. In contrast, firm-level contracting is less likely for private firms, for firms in sectors with higher hourly wage rates and higher return on assets, and in higher unemployment regions. Regarding wage floor outcomes, we observe that in all specifications the inverse Mills ratio is negative and statistically significant. In addition, the OLS estimates are smaller than the selectivity corrected ones indicating that wage reductions are higher when selection is being accounted for. This implies that firms who decided to engage in firm-level bargaining were more prone to wage reductions due to several sources of heterogeneity related to productivity and profitability. In other words, the probability of firm-level contracting was higher for firms from low productivity and low profitability sectors. However, conditional on participation these factors were associated with higher wage floors.

[Table 5 about here]

To address any concerns regarding our estimated reform impact being driven by firm size we perform some robustness checks by restricting the sample to narrower windows around the policy cutoff. More specifically, we restrict our analysis to firms with 5-99 employees and to firms with $25-75$ employees. The estimation results regarding the probability of firm-level contracting, wage floors and wage floor changes, i.e. the coefficient $\theta$ from equation 1 , are presented in Table 6. Column 1 (5-99 employees) of Table 6 corresponds to column 6 of Table 2 (likelihood of firm-level bargaining) and to columns 3 (wage floor level) and 6 (wage floor change) of Table 3. We observe that in all cases the estimated coefficients are very close in terms of magnitude and statistical significance, implying that our previous findings were not driven by firm size. This finding is further confirmed when we restrict our sample to firms with 25-75 employees (Column 4 of Table 6). However, the estimated coefficients are smaller due to the exclusion of a large part of the firms that were affected by the reform, i.e. those employing 5-24 employees. Columns 2 and 5 of Table 6 report sample selection corrected results using nominal base wage levels and changes as dependent variables. Again, these are 
very close to those obtained using the unrestricted samples (columns 3 and 6 of Table 4). Lastly, in columns 3 and 6 of Table 6 we present estimates from model specifications that include the additional variables shown in Table 5 (columns 1, 5 and 9). The obtained estimates are very similar indicating that firm size is not considered to be a threat for our identification strategy.

[Table 6 about here]

\subsection{Employment effects}

The preceding analysis indicated a post-reform shift towards a more decentralised wage bargaining structure which in turn resulted in increased wage flexibility. This implies that aligning wages with productivity may have positive employment effects. We estimate difference-in-differences models in order to test whether decentralised negotiations affected firm-specific employment. We define two periods, one before (2006-2011) and one after the reform (2012-2016) and two groups of firms. The treated group consists of firms that first signed a firm-level agreement after November 2011 and the group of not affected firms consists of all other firms, i.e. those without firm-level contracts and those that signed firm-level contracts before the reform. Since our dependent variable is the number of employees, we calculate the average number of employees for each firm in each period to end up with a total of 21,242 firms $(10,621$ firms in each period). While this strategy helps us to observe the same firm before and after the reform, it could introduce several biases regarding firm entry and exit, mergers and acquisitions, employment turnover or missing cells in the employment variable, especially for small-sized firms. Nevertheless, knowing the bargaining type of each firm allows for an empirical investigation of the impact of firm-level bargaining on employment in the post-2011 period.

We estimate several model specifications and the results are presented in Table 7 . The estimate of interest is the interaction term between a dummy variable indicating firm-level 
contracting only after the reform and a post-reform period indicator. Models also control for industry (NACE Rev.2.), region (NUTS II), pre-reform firm-specific employment and bargaining type within the firm (company or local trade union). Our preferred model is the one reported in column 5, where employment levels are conditioned on a full set of covariates and fixed effects. According to the results, affected firms that first signed firm-level contracts after the reform exhibited an 8.5 percent increase in their employment during the post-reform period. This implies that increased wage flexibility induced by the 2011 reform had had positive employment effects. This finding is robust to more parsimonious model specifications (columns 1-4) and seems to corroborate with the argument that it was easier for more productive firms were able to attract or retain their workforce after the reform in Greece (Bulman and Pisu, 2018). This preliminary evidence warrants further investigation by using more appropriate data and adopting formal labour demand models focusing on the structure of labour costs and the adoption of the National Minimum Wage in the post reform period (Brändle and Goerke, 2018).

[Table 7 about here]

\section{Conclusions}

Decentralised collective bargaining is commonly used as a wage setting mechanism to align wages and employment with prevailing economic conditions, especially during economic downturns. This paper is the first to examine the impact of the 2011 industrial relations reform in Greece on the probability of firm-level contracting and on bargained wage outcomes as well as to present some preliminary results on employment effects. Before the implementation of Law 4024/2011 firm-level negotiations between employers and their workforce were not allowed to firms employing less than 50 employees. After the reform firms with less than 50 employees became eligible for firm-level bargaining given that their employees are represented 
by either a trade union or an association of persons. Moreover, after the reform, wages set at the firm level are allowed to deviate below thresholds set at broader levels of bargaining, i.e. sectoral and occupational, but not the National Minimum Wage one.

This setting allowed us to examine the impact of the reform by applying a differencein-differences estimation strategy using firms with more than 50 employees as the control group and firms with less than 50 employees as the treatment group. We use the universe of firm-level collective agreements signed in Greece during the period 2006-2016 and match this information to firm-specific characteristics not only for firms covered by firm-level collective agreements but also for those not covered. Using linear probability and probit models we find that the probability of firm-level contracting increased about 4.8 percent the first post-reform year for affected firms. The impact on bargained wage outcomes was estimated using OLS and Heckman corrected models in order to account for non-random sorting of firms into decentralised negotiations. Our estimated difference-in-differences parameters suggest that nominal wage floors decreased by 12 percent during the first year after the reform for firms that became eligible for decentralised negotiations. Our results are robust to the inclusion of industry and time fixed effects and their interactions, as well as to additional covariates that control for firm-specific heterogeneity, local economic conditions, inter-sectoral differences and synchronisation with broader levels of collective bargaining. Moreover, we report an 8.5 percent increase in employment for firms that signed their first firm-level contract after the reform.

Overall, our paper is a first empirical examination regarding the impact of the 2011 reform using a uniquely developed firm-level panel dataset. In future research it will allow us to examine how wages and employment have responded during an institutionally eventful period were several reforms, e.g. the reduction of the National Minimum Wage, have been implemented in an attempt to deal with the ongoing economic crisis. 


\section{References}

Addison J.T., Portugal P. and Vilares H. (2017), "Unions and collective bargaining in the wake of the Great Recession: evidence from Portugal”, British Journal of Industrial Relations, 55(3): $551-576$

Aghion P., Bloom N., Blundell R., Griffith R. and Howitt P. (2005), "Competition and innovation: An inverted U relationship”, Quarterly Journal of Economics, 120(2): 701-728

Avouyi-Dovi S., Fougère D. and Gautier E. (2013), "Wage rigidity, collective bargaining, and the minimum wage: Evidence from French agreement data", Review of Economics and Statistics, 95(4): 1337-1351

Brändle, T., \& Goerke, L. (2018), “The one constant: a causal effect of collective bargaining on employment growth? Evidence from German linked- employer- employee data", Scottish Journal of Political Economy, 65(5): 445-478

Breda T. (2015), “Firms' rents, workers' bargaining power and the union wage premium”, Economic Journal, 125(589): 1616-1652

Bulman T. and Pisu M. (2018), "Generating employment, raising incomes and addressing poverty in Greece", OECD Economics Department Working Papers, No. 1505, OECD Publishing, Paris. http://dx.doi.org/10.1787/8eec4ced-en 
Card D. and de la Rica S. (2006), "Firm-level contracting and the structure of wages in Spain", Industrial and Labor Relations Review, 59(4): 573-92

Christofides N.L. and Stengos T. (2003), "Wage rigidity in Canadian collective bargaining agreements", Industrial and Labor Relations Review, 56(3): 429-448

de Pinto, M. (2017), "The Impact of Unionization Structures with Heterogeneous Firms and Rent- Sharing Motives", The Scandinavian Journal of Economics.

Dustmann C., Fitzenberger B., Schönberg U., and Spitz-Oener A. (2014), "From sick man of Europe to economic superstar: Germany's resurgent economy", Journal of Economic Perspectives, 28(1): 167-88

Fougère D., Gautier E. and Roux S. (2018), "Wage floor rigidity in industry-level agreements: Evidence from France", Labour Economics, 55: 72-97

Daouli J.J., Demoussis M., Giannakopoulos N. and Laliotis I. (2013), "Firm-level collective bargaining and wages in Greece: A quantile decomposition analysis", British Journal of Industrial Relations, 51(1):80-103

Daouli J.J., Demoussis M., Giannakopoulos N. and Laliotis I. (2016), “The 2011 industrial relations reform and nominal wage adjustments in Greece", Journal of Labor Research, 37(4): $460-483$ 
Druant M., Fabiani S., Kezdi G., Lamo A., Martins F. and Sabbatini R. (2012), “Firms' price and wage adjustment in Europe: Survey evidence on nominal stickiness", Labour Economics, 19: $772-782$

Guertzgen N. (2009), "Rent-sharing and collective bargaining coverage: Evidence from linked employer-employee data", Scandinavian Journal of Economics, 111(2): 323-349

Grullon, G., Larkin Y. and Michaely R. (2017), “Are US industries becoming more concentrated?", Unpublished working paper, Rice University, York University, and Cornell University

Heckman J.J. (1979), "Sample selection bias as a specification error”, Econometrica, 47(1):153161

Janssen S. (2017), "The decentralization of wage bargaining and income losses after worker displacement", Journal of the European Economic Association, 16(1): 77-122

Jimeno, J. F., \& Thomas, C. (2013), "Collective bargaining, firm heterogeneity and unemployment“, European Economic Review, 59, 63-79.

Katz, H. C. (1993), "The decentralization of collective bargaining: a literature review and comparative analysis“, Industrial and Labor Relations Review, 47(1), 3-22.

Le Bihan H., Montornès J. and Heckel T. (2012), "Sticky wages: Evidence from quarterly microeconomic data", American Economic Journal: Macroeconomics, 4(3): 1-32 
Lucifora C. and Origo F. (2015), "Performance-related pay and firm productivity: evidence from a reform in the structure of collective bargaining", Industrial and Labor Relations Review, 68(3): 606-632

Puhani P.A. (2000), “The Heckman correction for sample selection and its critique”, Journal of Economic Surveys, 14(1): 53-68

Puhani P.A. (2012), “The treatment effect, the cross difference, and the interaction term in nonlinear difference-in-differences models”, Economics Letters, 115: 85-87

van Ours et al. (2016), "Recommendations Expert Group for the review of the Greek labour market”, Review of Greek Labour Market Institutions, Ministry of Labour, Social Security and Welfare, September 2016, Athens

Voskeritsian H. and Kornelakis A. (2014), "The transformation of employment regulation in Greece: Towards a dysfunctional liberal market economy?”, Relation Industrielles/Industrial Relations, 69(2): 344-365 


\section{Figures}

Figure 1. Evolution of the frequency of firm level contracting for firms affected (5-50 employees) and not affected (>50 employees) by the reform

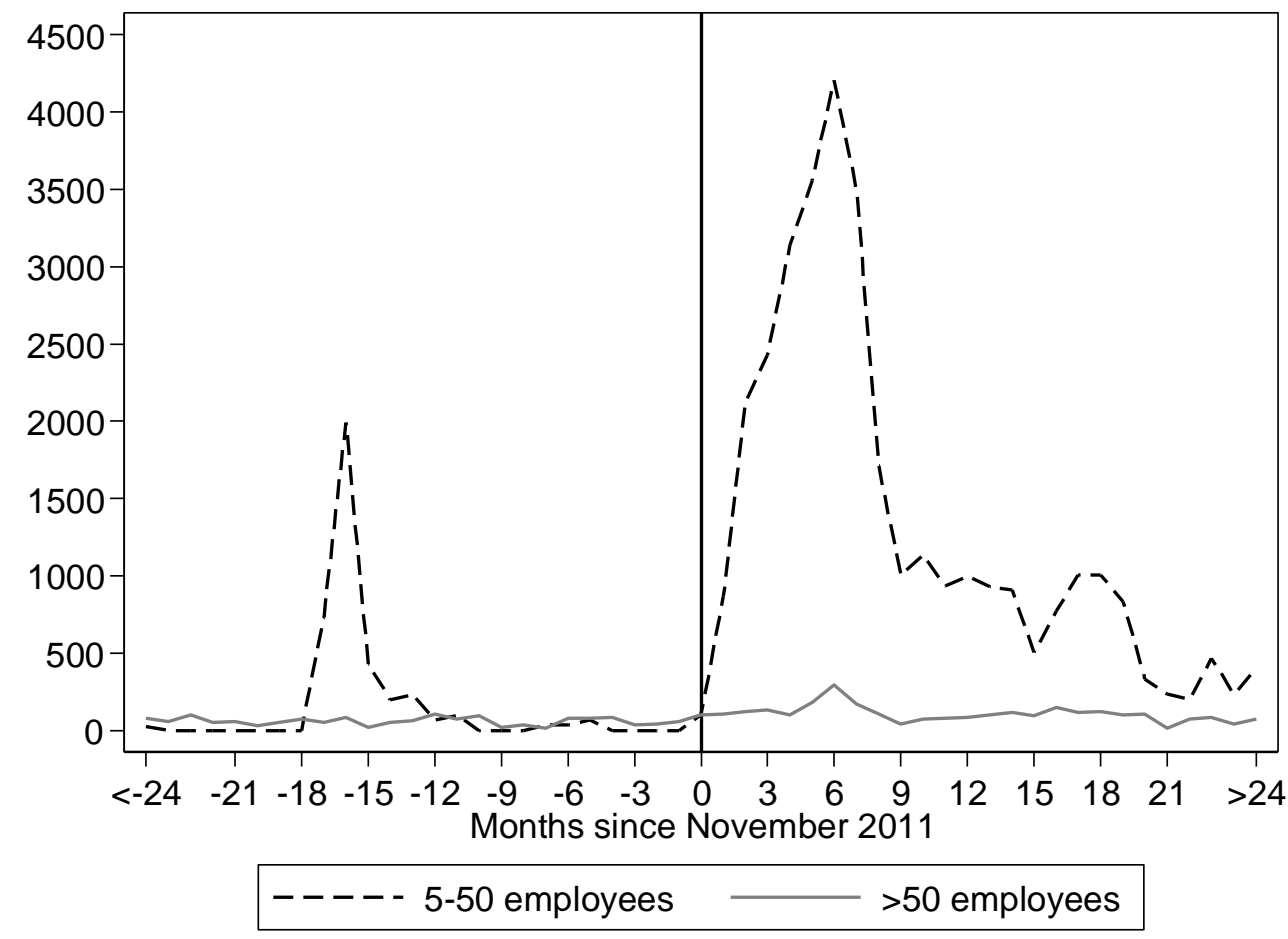

Source: Ministry of Labour, Social Security and Welfare, Greek Organisation for Mediation and Arbitration (OMED) and authors' calculations.

Notes: Vertical line indicates the implementation of Law 4024/2011. 
Figure 2. Timing of national collective bargaining, institutional reforms in collective bargaining and within-year monthly frequency of firm-level contracting

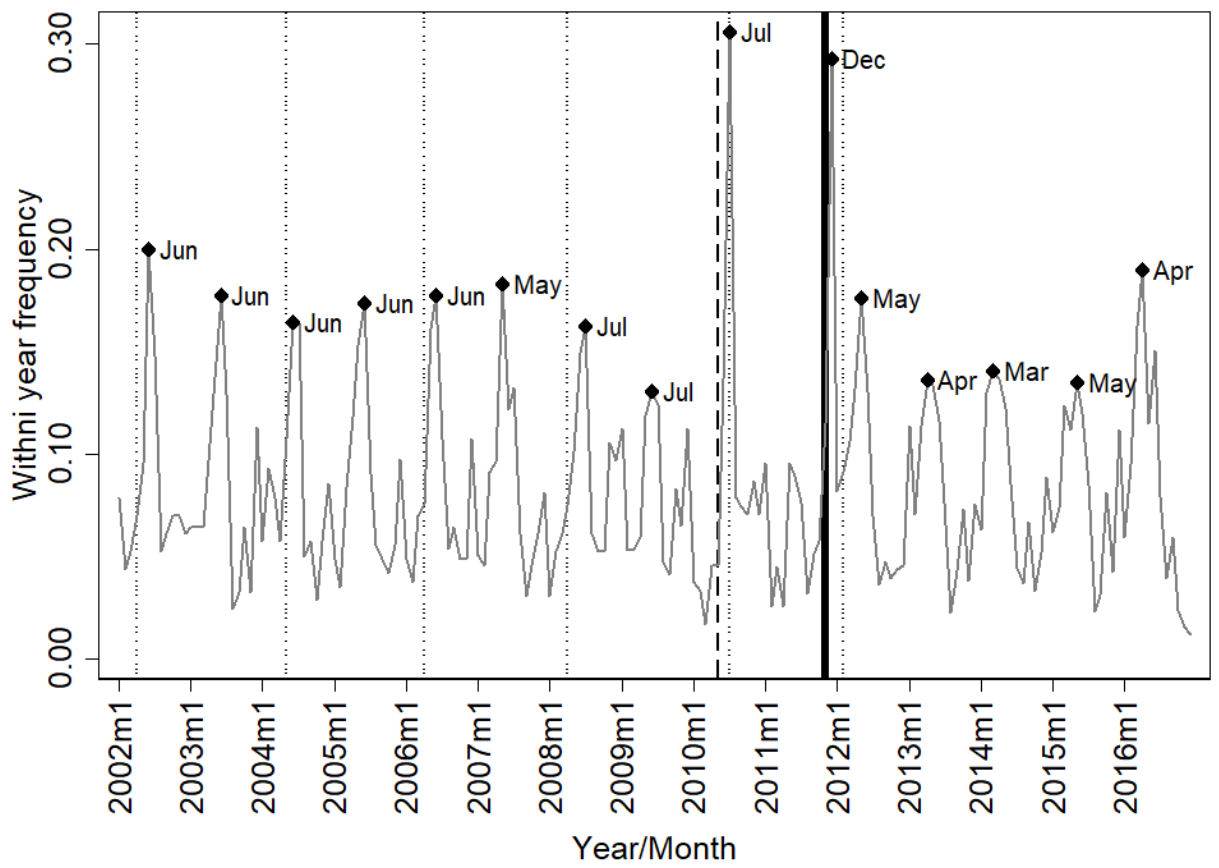

Source: Ministry of Labour, Social Security and Welfare, Greek Organisation for Mediation and Arbitration (OMED) and authors' calculations.

Notes: Black vertical dotted lines indicate the months when the National General Collective Agreement was signed. The black vertical dashed line $(2010 \mathrm{~m} 05)$ indicates the implementation of Law 3899/2010. The black vertical solid line(2011m11) indicates the implementation of Law $4024 / 2011$. 
Figure 3. Wage floors for firms affected (5-50 employees) and not affected $(>50$ employeed) before and after the reform

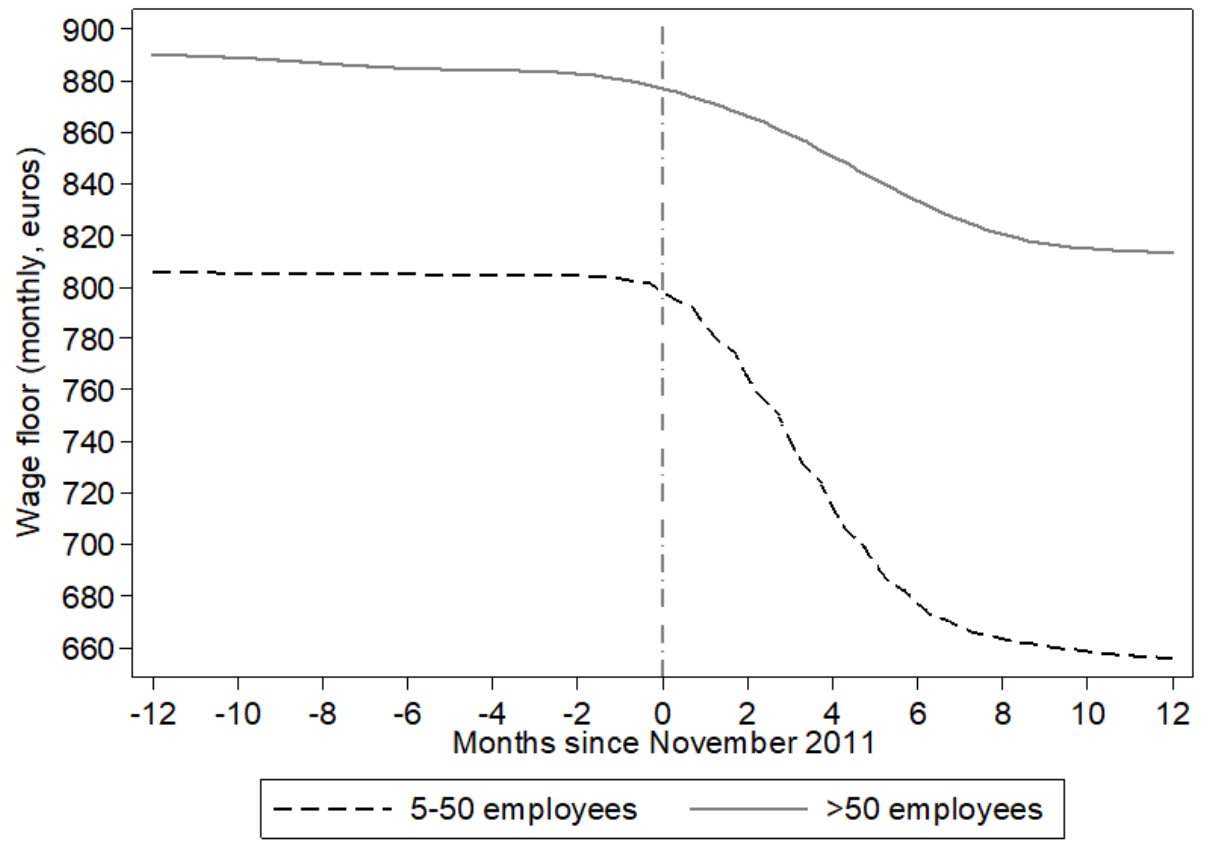

Source: Ministry of Labour, Social Security and Welfare, Greek Organisation for Mediation and Arbitration (OMED) and authors' calculations.

Notes: Local polynomial smooth plots. Vertical line indicates the implementation of Law 4024/2011. 
Figure 4. Wage floor changes for firms affected (5-50 employees) and not affected ( $>50$ employees) before and after the reform

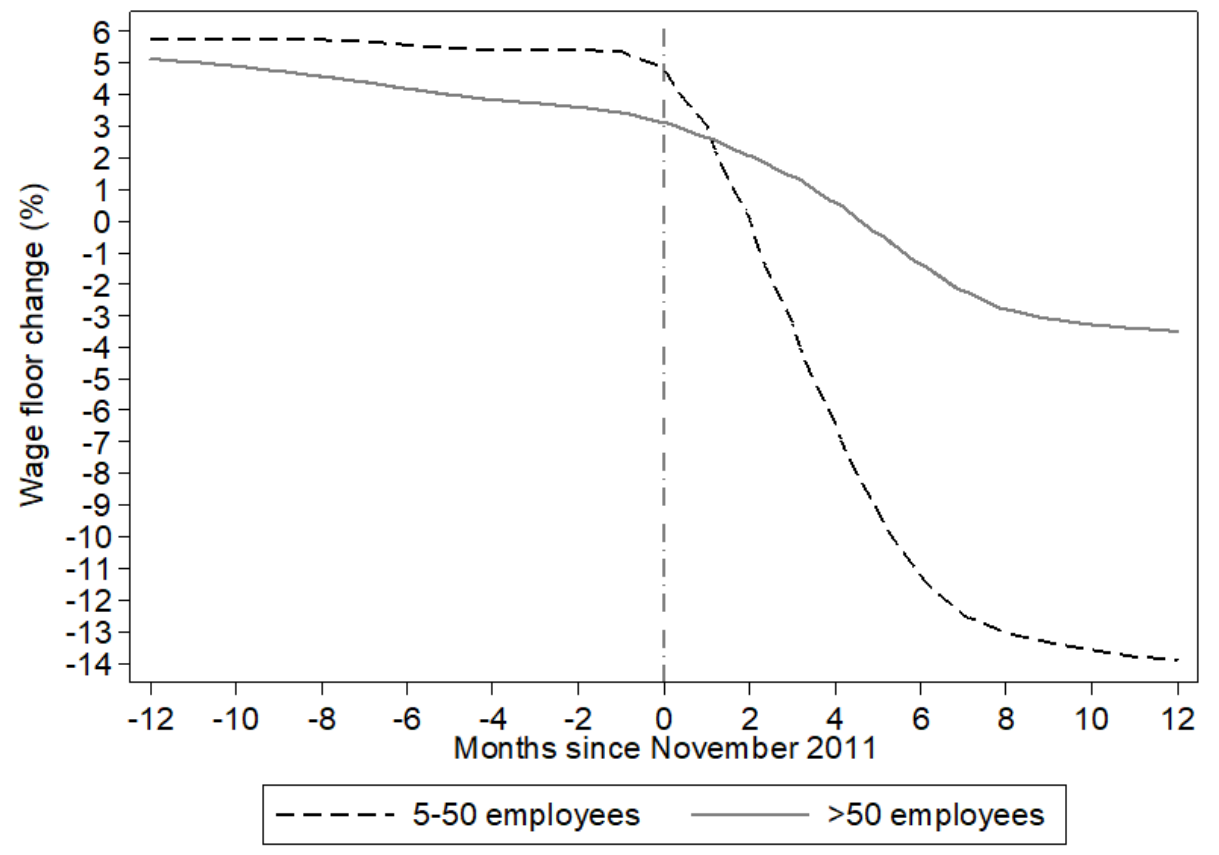

Source: Ministry of Labour, Social Security and Welfare, Greek Organisation for Mediation and Arbitration (OMED) and authors' calculations.

Notes: Local polynomial smooth plot. Vertical line indicates the implementation of Law 4024/2011. 


\section{Tables}

Table 1. Summary statistics and differences in firm-level bargaining outcomes before and after the 2011 reform

\begin{tabular}{|c|c|c|c|c|c|c|c|}
\hline & \multicolumn{3}{|c|}{ Not affected firms (>50 employees) } & \multicolumn{3}{|c|}{ Affected firms (5-50 employees) } & \multirow{2}{*}{$\begin{array}{c}\text { Difference }^{1} \\
{[6]-[3]}\end{array}$} \\
\hline & $\begin{array}{l}\text { pre } \\
{[1]}\end{array}$ & $\begin{array}{c}\text { post } \\
{[2]}\end{array}$ & $\begin{array}{l}\text { Difference }{ }^{1} \\
\text { [3]: [2]-[1] }\end{array}$ & $\begin{array}{l}\text { pre } \\
{[4]}\end{array}$ & $\begin{array}{c}\text { post } \\
{[5]}\end{array}$ & $\begin{array}{l}\text { Difference } \\
\text { [6]: [5]-[4] }\end{array}$ & \\
\hline Firm-level bargaining $(0 / 1)$ & $\begin{array}{l}.0039 \\
(.0001)\end{array}$ & $\begin{array}{l}.0045 \\
(.0002)\end{array}$ & $\begin{array}{c}.0006^{* * *} * \\
(.0002)\end{array}$ & $\begin{array}{c}.0002 \\
(.0001)\end{array}$ & $\begin{array}{l}.0017 \\
(.0001)\end{array}$ & $\begin{array}{c}.0015 * * * \\
(.0001)\end{array}$ & $\begin{array}{c}.0009 * * * \\
(.0001)\end{array}$ \\
\hline Wage floor ( $€$, monthly) & $\begin{array}{l}869.15 \\
(1.38)\end{array}$ & $\begin{array}{l}800.65 \\
(1.04)\end{array}$ & $\begin{array}{c}-67.81 * * * \\
(1.76)\end{array}$ & $\begin{array}{c}829.68 \\
(3.14)\end{array}$ & $\begin{array}{c}648.56 \\
(.45)\end{array}$ & $\begin{array}{c}-181.61 * * * \\
(2.22)\end{array}$ & $\begin{array}{c}-112.80 * * * \\
(3.07)\end{array}$ \\
\hline Wage floor (ln, monthly) & $\begin{array}{l}6.752 \\
(.002)\end{array}$ & $\begin{array}{l}6.664 \\
(.001)\end{array}$ & $\begin{array}{c}-.087 * * * \\
(.002)\end{array}$ & $\begin{array}{l}6.707 \\
(.003)\end{array}$ & $\begin{array}{l}6.463 \\
(.001)\end{array}$ & $\begin{array}{c}-.244 * * * \\
(.002)\end{array}$ & $\begin{array}{c}-.156^{* * * *} \\
(.004)\end{array}$ \\
\hline Wage floor change & $\begin{array}{l}.0614 \\
(.0004)\end{array}$ & $\begin{array}{l}-.0279 \\
(.0006)\end{array}$ & $\begin{array}{c}-.0894 * * * \\
(.0009)\end{array}$ & $\begin{array}{l}.0595 \\
(.0005)\end{array}$ & $\begin{array}{l}-.1206 \\
(.0005)\end{array}$ & $\begin{array}{c}-.1800 * * * \\
(.0005)\end{array}$ & $\begin{array}{c}-.0908 * * * \\
(.0024)\end{array}$ \\
\hline 5-50 employees $(0 / 1)$ & - & - & - & $\begin{array}{l}1.000 \\
(0.000)\end{array}$ & $\begin{array}{l}1.000 \\
(0.000)\end{array}$ & - & - \\
\hline 51-100 employees $(0 / 1)$ & $\begin{array}{l}.4680 \\
(.0011)\end{array}$ & $\begin{array}{l}.4562 \\
(.0012)\end{array}$ & - & - & - & - & - \\
\hline More than 100 employees $(0 / 1)$ & $\begin{array}{l}.5320 \\
(.0011)\end{array}$ & $\begin{array}{l}.5438 \\
(.0012)\end{array}$ & - & - & - & - & - \\
\hline Private company $(0 / 1)$ & $\begin{array}{l}.9600 \\
(.0005)\end{array}$ & $\begin{array}{l}.9400 \\
(.0005)\end{array}$ & - & $\begin{array}{l}.9759 \\
(.0002)\end{array}$ & $\begin{array}{l}.9655 \\
(.0002)\end{array}$ & - & - \\
\hline Average hourly wage $(€)$ & $\begin{array}{l}3.2650 \\
(.0004)\end{array}$ & $\begin{array}{l}3.1085 \\
(.0005)\end{array}$ & - & $\begin{array}{l}3.229 \\
(.0002)\end{array}$ & $\begin{array}{l}3.0723 \\
(.0002)\end{array}$ & - & - \\
\hline Return on assets & $\begin{array}{l}-.0279 \\
(.0001)\end{array}$ & $\begin{array}{l}-.0257 \\
(.0001)\end{array}$ & - & $\begin{array}{l}-.0311 \\
(.0001)\end{array}$ & $\begin{array}{l}-.0299 \\
(.0001)\end{array}$ & - & - \\
\hline Price cost margin & $\begin{array}{l}-.0357 \\
(.0001)\end{array}$ & $\begin{array}{l}-.0194 \\
(.0001)\end{array}$ & - & $\begin{array}{l}-.0411 \\
(.0003)\end{array}$ & $\begin{array}{l}-.0244 \\
(.0004)\end{array}$ & - & - \\
\hline Local unemployment rate & $\begin{array}{l}.1036 \\
(.0001)\end{array}$ & $\begin{array}{l}.2568 \\
(.0001)\end{array}$ & - & $\begin{array}{l}.1052 \\
(.0001)\end{array}$ & $\begin{array}{l}.2559 \\
(.0002)\end{array}$ & - & - \\
\hline Local unemployment growth & $\begin{array}{l}.1119 \\
(.0006)\end{array}$ & $\begin{array}{l}.0747 \\
(.0005)\end{array}$ & & $\begin{array}{l}.1131 \\
(.0002)\end{array}$ & $\begin{array}{l}.0803 \\
(.0002)\end{array}$ & - & - \\
\hline Sectoral wage agreement $(0 / 1)$ & $\begin{array}{l}.8301 \\
(.0009)\end{array}$ & $\begin{array}{l}.7948 \\
(.0010)\end{array}$ & & $\begin{array}{l}.8245 \\
(.0004)\end{array}$ & $\begin{array}{l}.7923 \\
(.0004)\end{array}$ & - & - \\
\hline Company Trade Union $(0 / 1)$ & $\begin{array}{l}.0705 \\
(.0006)\end{array}$ & $\begin{array}{l}.1300 \\
(.0008)\end{array}$ & - & $\begin{array}{l}.0010 \\
(.0001)\end{array}$ & $\begin{array}{l}.0020 \\
(.0001)\end{array}$ & - & - \\
\hline Local Trade Union $(0 / 1)$ & $\begin{array}{l}.0013 \\
(.0001)\end{array}$ & $\begin{array}{l}.0046 \\
(.0002)\end{array}$ & - & $\begin{array}{l}.0019 \\
(.0001)\end{array}$ & $\begin{array}{l}.0138 \\
(.0001)\end{array}$ & - & - \\
\hline Association of persons $(0 / 1)$ & - & $\begin{array}{l}.0225 \\
(.0004)\end{array}$ & - & - & $\begin{array}{l}.0537 \\
(.0002)\end{array}$ & - & - \\
\hline Eastern Macedonia and Thrace & $\begin{array}{l}.0272 \\
(.0003)\end{array}$ & $\begin{array}{l}.0333 \\
(.0004)\end{array}$ & - & $\begin{array}{l}.0325 \\
(.0002)\end{array}$ & $\begin{array}{l}.0345 \\
(.0002)\end{array}$ & - & - \\
\hline Central Macedonia & $\begin{array}{l}.1271 \\
(.0007)\end{array}$ & $\begin{array}{l}.1345 \\
(.0008)\end{array}$ & - & $\begin{array}{l}.1470 \\
(.0003)\end{array}$ & $\begin{array}{l}.1633 \\
(.0004)\end{array}$ & - & - \\
\hline Western Macedonia & $\begin{array}{l}.0063 \\
(.0001)\end{array}$ & $\begin{array}{l}.0093 \\
(.0002)\end{array}$ & - & $\begin{array}{l}.0120 \\
(.0001)\end{array}$ & $\begin{array}{l}.0134 \\
(.0001)\end{array}$ & - & - \\
\hline Thessaly & $\begin{array}{l}.0312 \\
(.0004)\end{array}$ & $\begin{array}{l}.0351 \\
(.0004)\end{array}$ & - & $\begin{array}{l}.0387 \\
(.0002)\end{array}$ & $\begin{array}{l}.0397 \\
(.0002)\end{array}$ & - & - \\
\hline Epirus & $\begin{array}{l}.0121 \\
(.0003)\end{array}$ & $\begin{array}{l}.0136 \\
(.0002)\end{array}$ & - & $\begin{array}{l}.0166 \\
(.0001)\end{array}$ & $\begin{array}{l}.0200 \\
(.0001)\end{array}$ & - & - \\
\hline Ionian Islands & $\begin{array}{l}.0046 \\
(.0001)\end{array}$ & $\begin{array}{l}.0046 \\
(.0001)\end{array}$ & - & $\begin{array}{l}.0162 \\
(.0001)\end{array}$ & $\begin{array}{l}.0143 \\
(.0001)\end{array}$ & - & - \\
\hline Western Greece & $\begin{array}{l}.0204 \\
(.0003)\end{array}$ & $\begin{array}{l}.0232 \\
(.0003)\end{array}$ & - & $\begin{array}{l}.0348 \\
(.0002)\end{array}$ & $\begin{array}{l}.0341 \\
(.0002)\end{array}$ & - & - \\
\hline Central Greece & $\begin{array}{l}.0427 \\
(.0379)\end{array}$ & $\begin{array}{l}.0379 \\
(.0004)\end{array}$ & - & $\begin{array}{l}.0548 \\
(.0002)\end{array}$ & $\begin{array}{c}.0497 \\
(.0002)\end{array}$ & - & - \\
\hline Peloponnese & $\begin{array}{l}.0191 \\
(.0003)\end{array}$ & $\begin{array}{c}.0206 \\
(.0003)\end{array}$ & - & $\begin{array}{l}.0273 \\
(.0002)\end{array}$ & $\begin{array}{c}.0279 \\
(.0002)\end{array}$ & - & - \\
\hline Attica & $\begin{array}{l}.6709 \\
(.0011)\end{array}$ & $\begin{array}{c}.6478 \\
(.0011)\end{array}$ & - & $\begin{array}{l}.5472 \\
(.0005)\end{array}$ & $\begin{array}{l}.5287 \\
(.0005)\end{array}$ & - & - \\
\hline North Aegean & $\begin{array}{c}.0043 \\
(.0001)\end{array}$ & $\begin{array}{c}.0053 \\
(.0001)\end{array}$ & - & $\begin{array}{l}.0106 \\
(.0001)\end{array}$ & $\begin{array}{c}.0099 \\
(.0001)\end{array}$ & - & - \\
\hline South Aegean & $\begin{array}{c}.0041 \\
(.0001)\end{array}$ & $\begin{array}{c}.0047 \\
(.0001)\end{array}$ & - & $\begin{array}{c}.0084 \\
(.0001)\end{array}$ & $\begin{array}{c}.0124 \\
(.0001)\end{array}$ & - & - \\
\hline Crete & $\begin{array}{l}.0296 \\
(.0004)\end{array}$ & $\begin{array}{c}.0297 \\
(.0004)\end{array}$ & - & $\begin{array}{l}.0533 \\
(.0002)\end{array}$ & $\begin{array}{l}.0506 \\
(.0002)\end{array}$ & - & - \\
\hline Manufacturing, mining & $\begin{array}{l}.1288 \\
(.0007)\end{array}$ & $\begin{array}{l}.1367 \\
(.0008)\end{array}$ & - & $\begin{array}{l}.1207 \\
(.0003)\end{array}$ & $\begin{array}{l}.1221 \\
(.0003)\end{array}$ & - & - \\
\hline Water supply; sewerage, etc. & $\begin{array}{c}.0157 \\
(.0003)\end{array}$ & $\begin{array}{c}.0205 \\
(.0003)\end{array}$ & - & $\begin{array}{l}.0067 \\
(.0008)\end{array}$ & $\begin{array}{c}.0066 \\
(.0001)\end{array}$ & - & - \\
\hline Construction & $\begin{array}{l}.0046 \\
(.0001)\end{array}$ & $\begin{array}{c}.0114 \\
(.0002)\end{array}$ & - & $\begin{array}{l}.0113 \\
(.0001)\end{array}$ & $\begin{array}{l}.0315 \\
(.0002)\end{array}$ & - & - \\
\hline
\end{tabular}




\begin{tabular}{|c|c|c|c|c|c|c|c|}
\hline Wholesale and retail trade & $\begin{array}{c}.3161 \\
(.0011)\end{array}$ & $\begin{array}{c}.2932 \\
(.0011)\end{array}$ & - & $\begin{array}{c}.3996 \\
(.0005)\end{array}$ & $\begin{array}{c}.3695 \\
(.0005)\end{array}$ & - & - \\
\hline Transportation and storage & $\begin{array}{c}.0567 \\
(.0005)\end{array}$ & $\begin{array}{c}.0599 \\
(.0006)\end{array}$ & - & $\begin{array}{c}.0420 \\
(.0002)\end{array}$ & $\begin{array}{c}.0447 \\
(.0002)\end{array}$ & - & - \\
\hline Accommodation and food & $\begin{array}{c}.0478 \\
(.0005)\end{array}$ & $\begin{array}{c}.0476 \\
(.0005)\end{array}$ & - & $\begin{array}{c}.0798 \\
(.0002)\end{array}$ & $\begin{array}{c}.0823 \\
(.0003)\end{array}$ & - & - \\
\hline Financial services & $\begin{array}{c}.0557 \\
(.0005)\end{array}$ & $\begin{array}{c}.0550 \\
(.0006)\end{array}$ & - & $\begin{array}{c}.0212 \\
(.0001)\end{array}$ & $\begin{array}{c}.0195 \\
(.0001)\end{array}$ & - & - \\
\hline Real estate activities & $\begin{array}{c}.0355 \\
(.0004)\end{array}$ & $\begin{array}{c}.0430 \\
(.0005)\end{array}$ & - & $\begin{array}{c}.0407 \\
(.0002)\end{array}$ & $\begin{array}{c}.0478 \\
(.0002)\end{array}$ & - & - \\
\hline Professional, scientific etc. & $\begin{array}{c}.1018 \\
(.0007)\end{array}$ & $\begin{array}{c}.0980 \\
(.0007)\end{array}$ & - & $\begin{array}{c}.0925 \\
(.0002)\end{array}$ & $\begin{array}{c}.0898 \\
(.0003)\end{array}$ & - & - \\
\hline Administrative activities & $\begin{array}{c}.1388 \\
(.0008)\end{array}$ & $\begin{array}{l}.1320 \\
(.0008)\end{array}$ & - & $\begin{array}{l}.1240 \\
(.0003)\end{array}$ & $\begin{array}{l}.1200 \\
(.0003)\end{array}$ & - & - \\
\hline Public administration & $\begin{array}{c}.0707 \\
(.0006)\end{array}$ & $\begin{array}{c}.0747 \\
(.0006)\end{array}$ & - & $\begin{array}{c}.0399 \\
(.0002)\end{array}$ & $\begin{array}{c}.0446 \\
(.0002)\end{array}$ & - & - \\
\hline Other service activities & $\begin{array}{c}.0272 \\
(.0004)\end{array}$ & $\begin{array}{c}.0274 \\
(.0004)\end{array}$ & - & $\begin{array}{c}.0210 \\
(.0001)\end{array}$ & $\begin{array}{c}.0212 \\
(.0001)\end{array}$ & - & - \\
\hline Observations & 177,205 & 161,716 & - & 893,475 & 807,572 & - & - \\
\hline
\end{tabular}


Table 2. Differential impact of the 2011 reform on firm-level contracting

\begin{tabular}{|c|c|c|c|c|c|c|}
\hline & \multicolumn{3}{|c|}{ OLS } & \multicolumn{3}{|c|}{ Probit } \\
\hline & [1] & [2] & [3] & [4] & {$[5]$} & {$[6]$} \\
\hline Post $\times 5-50$ employees & $.0010^{* * * *}$ & $.0010^{* * *}$ & $.0009 * * *$ & $.0015^{* * *}$ & $.0015^{* * *}$ & $.0014 * * *$ \\
\hline & $(.0002)$ & $(.0002)$ & $(.0002)$ & $(.0001)$ & $(.0001)$ & $(.0001)$ \\
\hline & Size & Size & Industry $\times$ Size & Size & Size & Industry $\times$ Size \\
\hline Fixed effects & Year & Month & $\begin{array}{c}\text { Industry } \times \text { Year } \\
\text { Month }\end{array}$ & Year & Month & $\begin{array}{c}\text { Industry } \times \text { Year } \\
\text { Month }\end{array}$ \\
\hline
\end{tabular}

Source: Ministry of Labour, Social Security and Welfare, Greek Organization for Mediation and Arbitration (OMED) and ICAP (20062016). Authors' calculations.

Notes: Observations (monthly) $=2,039,968$. Firms $=22,909$. The post-reform period dummy is equal to 1 for the period November 2011 December 2016 and 0 for January 2006-October 2011. In columns 4-6 probit marginal effects are reported (Puhani, 2012). Industry dummies correspond to NACE Rev. 2, 1 digit and size dummies to 3 categories of firm-size, i.e., 5-50 employees, 51-100 employees and more than 100 employees. Standard errors in parentheses are clustered at the firm-level.

$* * * \mathrm{p}<0.01, * * \mathrm{p}<0.05, * \mathrm{p}<0.10$ 
Table 3. Differential impact of the 2011 reform on wage floor outcomes

\begin{tabular}{|c|c|c|c|c|c|c|}
\hline & \multicolumn{3}{|c|}{ Wage floor level } & \multicolumn{3}{|c|}{ Wage floor change } \\
\hline & [1] & {$[2]$} & [3] & [4] & [5] & [6] \\
\hline Post $\times 5-50$ employees & $\begin{array}{c}-.149 * * * \\
(.024)\end{array}$ & $\begin{array}{c}-.155 * * * \\
(.024)\end{array}$ & $\begin{array}{c}-.110 * * * \\
(.024)\end{array}$ & $\begin{array}{c}-.101 * * * * \\
(.006)\end{array}$ & $\begin{array}{c}-.100 * * * \\
(.006)\end{array}$ & $\begin{array}{c}-.080 * * * \\
(.008)\end{array}$ \\
\hline Fixed effects & $\begin{array}{l}\text { Size } \\
\text { Year }\end{array}$ & $\begin{array}{c}\text { Size } \\
\text { Month }\end{array}$ & $\begin{array}{c}\text { Industry } \times \text { Size } \\
\text { Industry } \times \text { Year } \\
\text { Month }\end{array}$ & $\begin{array}{l}\text { Size } \\
\text { Year }\end{array}$ & $\begin{array}{c}\text { Size } \\
\text { Month }\end{array}$ & $\begin{array}{c}\text { Industry } \times \text { Size } \\
\text { Industry } \times \text { Year } \\
\text { Month }\end{array}$ \\
\hline
\end{tabular}

Source: Ministry of Labour, Social Security and Welfare, Greek Organization for Mediation and Arbitration (OMED) and ICAP (20062016). Authors' calculations.

Notes: Observations (monthly) $=96,813$. Firms $=1,538$. The post-reform period dummy is equal to 1 for the period November 2011 December 2016 and 0 for January 2006-October 2011. Industry dummies correspond to NACE Rev. 2, 1 digit and size dummies to 3 categories of firm-size, i.e., 5-50 employees, 51-100 employees and more than 100 employees. Wage floors are CPI deflated (2015=100). Standard errors in parentheses are clustered at the firm-level.

$* * * \mathrm{p}<0.01, * * \mathrm{p}<0.05, * \mathrm{p}<0.10$ 
Table 4. Differential impact of the 2011 reform on wage floor outcomes (corrected for sample selection)

\begin{tabular}{|c|c|c|c|c|c|c|}
\hline & \multicolumn{3}{|c|}{ Wage floor level } & \multicolumn{3}{|c|}{ Wage floor change } \\
\hline & [1] & {$[2]$} & {$[3]$} & [4] & {$[5]$} & {$[6]$} \\
\hline \multirow[t]{2}{*}{ Post $\times 5-50$ employees } & $-.151 * * *$ & $-.156 * * *$ & $-.132 * * *$ & $-.098 * * *$ & $-.100 * * *$ & $-.050 * * *$ \\
\hline & $(.020)$ & $(.021)$ & $(.031)$ & $(.006)$ & $(.007)$ & $(.009)$ \\
\hline \multirow[t]{2}{*}{ Inverse Mills Ratio } & $-.209 * * *$ & $-.204 * * *$ & $-.182 * * *$ & $-.132 * * *$ & $-.128 * * *$ & $-.058 * * *$ \\
\hline & $(.007)$ & $(.008)$ & $(.014)$ & $(.005)$ & $(.005)$ & $(.005)$ \\
\hline \multirow[b]{2}{*}{ Fixed effects } & Size & Size & Industry $\times$ Size & Size & Size & Industry $\times$ Size \\
\hline & Year & Month & $\begin{array}{c}\text { Industry } \times \text { Year } \\
\text { Month }\end{array}$ & Year & Month & $\begin{array}{c}\text { Industry } \times \text { Year } \\
\text { Month }\end{array}$ \\
\hline Exclusion restriction & \multicolumn{6}{|c|}{ Bargaining type } \\
\hline
\end{tabular}

Source: Ministry of Labour, Social Security and Welfare, Greek Organization for Mediation and Arbitration (OMED) and ICAP (20062016). Authors' calculations.

Notes: Observations (monthly)=96,813. Firms $=1,538$. The post-reform period dummy is equal to 1 for the period November 2011 December 2016 and 0 for January 2006-October 2011. Industry dummies correspond to NACE Rev. 2, 1 digit and size dummies to 3 categories of firm-size, i.e., 5-50 employees, 51-100 employees and more than 100 employees. The Inverse Mills Ratio corresponds to specifications (4-6) reported in Table 2. Bargaining type (included only in probit equations) corresponds to whether a company trade union or a local trade union operates within firm (fixed effect). Wage floors are CPI deflated (2015=100). Standard errors in parentheses are clustered at the firm-level.

$* * * \mathrm{p}<0.01, * * \mathrm{p}<0.05, * \mathrm{p}<0.10$ 
Table 5. Differential impact of the 2011 reform on wage floor outcomes (sample selection correction with additional controls)

\begin{tabular}{|c|c|c|c|c|c|c|c|c|c|c|}
\hline & \multicolumn{2}{|c|}{ Firm-level bargaining } & \multicolumn{4}{|c|}{ Wage floor level } & \multicolumn{4}{|c|}{ Wage floor change } \\
\hline & [1] & [2] & [3] & [4] & [5] & [6] & [7] & [8] & [9] & [10] \\
\hline & $\begin{array}{l}\text { Jan 2006- } \\
\text { Dec } 2016\end{array}$ & $\begin{array}{l}\text { Nov 2010- } \\
\text { Dec } 2012\end{array}$ & $\begin{array}{l}\text { Jan 2006- } \\
\text { Dec } 2016\end{array}$ & $\begin{array}{l}\text { Nov 2010- } \\
\text { Dec } 2012\end{array}$ & $\begin{array}{l}\text { Jan 2006- } \\
\text { Dec } 2016\end{array}$ & $\begin{array}{l}\text { Nov 2010- } \\
\text { Dec } 2012\end{array}$ & $\begin{array}{l}\text { Jan 2006- } \\
\text { Dec } 2016\end{array}$ & $\begin{array}{l}\text { Nov 2010- } \\
\text { Dec } 2012\end{array}$ & $\begin{array}{l}\text { Jan 2006- } \\
\text { Dec } 2016\end{array}$ & $\begin{array}{r}\text { Nov } 2010 \\
\text { Dec } 2012\end{array}$ \\
\hline & \multicolumn{2}{|c|}{ Probit } & \multicolumn{2}{|c|}{ OLS } & \multicolumn{2}{|c|}{ Heckman } & \multicolumn{2}{|c|}{ OLS } & \multicolumn{2}{|c|}{ Heckman } \\
\hline Post $\times 5-50$ employees & $\begin{array}{c}.0015^{* * * *} \\
(.001)\end{array}$ & $\begin{array}{c}.0040 * * * \\
(.0001)\end{array}$ & $\begin{array}{c}-.132 * * * \\
(.034)\end{array}$ & $\begin{array}{c}-.110^{* *} \\
(.061)\end{array}$ & $\begin{array}{c}-.121 * * * \\
(.032)\end{array}$ & $\begin{array}{c}-.193^{* * *} * \\
(.066)\end{array}$ & $\begin{array}{c}-.045^{* * * *} \\
(.009)\end{array}$ & $\begin{array}{l}-.033^{*} \\
(.019)\end{array}$ & $\begin{array}{c}-.041 * * * * \\
(.009)\end{array}$ & $\begin{array}{c}-.086^{* * * *} \\
(.022)\end{array}$ \\
\hline Private company & $\begin{array}{c}-.0004^{* *} * \\
(.0002)\end{array}$ & $\begin{array}{c}-.0008 * * * \\
(.0004)\end{array}$ & $\begin{array}{c}-.038 * * * \\
(.016)\end{array}$ & $\begin{array}{l}-.038^{*} \\
(.021)\end{array}$ & $\begin{array}{c}.003 \\
(.017)\end{array}$ & $\begin{array}{c}.003 \\
(.020)\end{array}$ & $\begin{array}{c}-.013 * * * \\
(.004)\end{array}$ & $\begin{array}{l}-.005 \\
(.012)\end{array}$ & $\begin{array}{l}.001 \\
(.005)\end{array}$ & $\begin{array}{c}.020 \\
(.013)\end{array}$ \\
\hline Average hourly wage & $\begin{array}{c}-.0008 * * \\
(.0003)\end{array}$ & $\begin{array}{c}-.0024 * * * * \\
(.0007)\end{array}$ & $\begin{array}{c}.222 * * * * \\
(.037)\end{array}$ & $\begin{array}{c}.263^{* * * *} \\
(.036)\end{array}$ & $\begin{array}{c}.140 \text { **** } \\
(.033)\end{array}$ & $\begin{array}{c}.155^{* * * *} \\
(.034)\end{array}$ & $\begin{array}{c}.089 * * * \\
(.014)\end{array}$ & $\begin{array}{c}.172 * * * * \\
(.023)\end{array}$ & $\begin{array}{c}.062 * * * \\
(.014)\end{array}$ & $\begin{array}{c}.103^{* * * *} \\
(.021)\end{array}$ \\
\hline Return on assets & $\begin{array}{c}.0006 \\
(.0026)\end{array}$ & $\begin{array}{c}-.0333 * * * \\
(.0081)\end{array}$ & $\begin{array}{l}.876 * * \\
(.373)\end{array}$ & $\begin{array}{l}.919 * * \\
(.397)\end{array}$ & $\begin{array}{l}.643 * * \\
(.343)\end{array}$ & $\begin{array}{c}1.722 * * * \\
(.402)\end{array}$ & $\begin{array}{c}.084 \\
(.088)\end{array}$ & $\begin{array}{l}-.071 \\
(.193)\end{array}$ & $\begin{array}{l}.006 \\
. .087)\end{array}$ & $\begin{array}{c}.412^{* * * *} \\
(.195)\end{array}$ \\
\hline Price cost margin & $\begin{array}{c}-.0038^{* * *} \\
(.0017)\end{array}$ & $\begin{array}{c}.0012 \\
(.0041)\end{array}$ & $\begin{array}{c}.146 \\
(.243)\end{array}$ & $\begin{array}{l}-.032 \\
.255)\end{array}$ & $\begin{array}{c}.029 \\
(.231)\end{array}$ & $\begin{array}{l}-.445^{*} \\
(.245)\end{array}$ & $\begin{array}{l}-.122 \\
(.092)\end{array}$ & $\begin{array}{l}-.129 \\
(.158)\end{array}$ & $\begin{array}{l}-.62^{* * *} \\
(.090)\end{array}$ & $\begin{array}{c}-.397 * * * \\
(.152)\end{array}$ \\
\hline Local unemployment rate & $\begin{array}{c}-.0010^{* *} \\
(.0003)\end{array}$ & $\begin{array}{c}-.0057 * * * \\
(.002)\end{array}$ & $\begin{array}{l}.082 \\
(.052)\end{array}$ & $\begin{array}{l}.081 \\
(.100)\end{array}$ & $\begin{array}{l}.093 \\
(.055)\end{array}$ & $\begin{array}{l}.143 \\
(.099)\end{array}$ & $\begin{array}{l}.012 \\
(.016)\end{array}$ & $\begin{array}{l}-.033 \\
(.078)\end{array}$ & $\begin{array}{l}.016 \\
(.017)\end{array}$ & $\begin{array}{l}0.283 \\
(.076)\end{array}$ \\
\hline Local unemployment growth & $\begin{array}{c}.0006 * * * \\
(.0002)\end{array}$ & $\begin{array}{c}.0025 * * * \\
(.0009)\end{array}$ & $\begin{array}{l}-.032 \\
(.033)\end{array}$ & $\begin{array}{l}-.007 \\
(.054)\end{array}$ & $\begin{array}{l}-.056^{*} \\
(.031)\end{array}$ & $\begin{array}{l}-.045 \\
(.051)\end{array}$ & $\begin{array}{l}.010 \\
(.017)\end{array}$ & $\begin{array}{c}.042 \\
(.034)\end{array}$ & $\begin{array}{l}.002 \\
. .017)\end{array}$ & $\begin{array}{c}.008 \\
(.032)\end{array}$ \\
\hline Sectoral wage agreement & $\begin{array}{l}-.0001 \\
(.0001)\end{array}$ & $\begin{array}{l}.0004 \\
(.0003)\end{array}$ & $\begin{array}{l}.034 * * \\
(.017)\end{array}$ & $\begin{array}{c}.024 \\
(.015)\end{array}$ & $\begin{array}{l}.030^{*} \\
(.016)\end{array}$ & $\begin{array}{l}-.004 \\
(.014)\end{array}$ & $\begin{array}{c}.014 * * * * \\
(.005)\end{array}$ & $\begin{array}{c}.029 * * * \\
(.008)\end{array}$ & $\begin{array}{c}.013^{* * * *} \\
(.005)\end{array}$ & $\begin{array}{l}.008 \\
(.008)\end{array}$ \\
\hline Company Trade Union & $\begin{array}{c}.0391 * * * \\
(.0025)\end{array}$ & $\begin{array}{c}.0378 * * * \\
(.0037)\end{array}$ & - & - & - & - & - & - & - & - \\
\hline Local Trade Union & $\begin{array}{c}.0170 \text { *** } \\
(.0016)\end{array}$ & $\begin{array}{c}.0245 * * * \\
(.0029)\end{array}$ & - & - & - & - & - & - & - & - \\
\hline Inverse Mills Ratio & - & - & - & - & $\begin{array}{c}-.166 * * * \\
(.015) \\
\end{array}$ & $\begin{array}{c}-.192 * * * \\
(.016) \\
\end{array}$ & - & - & $\begin{array}{c}-.056 * * * \\
(.005) \\
\end{array}$ & $\begin{array}{c}-.121 * * * \\
(.010) \\
\end{array}$ \\
\hline Observations & $2,039,968$ & 415,163 & 2,912 & 1,130 & 2,912 & 1,130 & 2,912 & 1,130 & 2,912 & 1,130 \\
\hline
\end{tabular}

Source: Ministry of Labour, Social Security and Welfare, Greek Organization for Mediation and Arbitration (OMED) and ICAP (2006-2016). Authors' calculations.

Notes: The post-reform period dummy is equal to 1 for the period November 2011-December 2016 and 0 for January 2006-October 2011. For the period November 2010-November 2012 the post period dummy indicator is equal to 1 for the period November 2011-November 2011 and 0 otherwise. Industry dummies correspond to NACE Rev. 2, 1 digit and size dummies to 3 categories of firm-size, i.e., 5-50 employees, 51 -

100 employees and more than 100 employees. The Inverse Mills Ratio is derived from the probit model specification reported in Columns 1 and 2 depending on the period of analysis. In columns 1-2 probit marginal effects are reported (Puhani, 2012). Wage floors are CPI deflated $(2015=100)$. All models include regional fixed effects (NUT2). Standard errors in parentheses are clustered at the firm-level.

$* * * \mathrm{p}<0.01, * * \mathrm{p}<0.05, * \mathrm{p}<0.10$ 
Table 6. Differential impact of the 2011 reform on wage floor outcomes: robustness analysis

\begin{tabular}{|c|c|c|c|c|c|c|}
\hline & \multicolumn{3}{|c|}{ [5-99 employees] } & \multicolumn{3}{|c|}{ [25-75 employees] } \\
\hline & [1] & [2] & [3] & [4] & [5] & [6] \\
\hline Firm-level bargaining & $\begin{array}{c}.0013 * * * \\
(.0001)\end{array}$ & - & $\begin{array}{c}.0014 * * * \\
(.0001)\end{array}$ & $\begin{array}{c}.0008 * * * \\
(.0002)\end{array}$ & - & $\begin{array}{c}.0011^{* * * *} \\
(.0002)\end{array}$ \\
\hline Wage floor level & $\begin{array}{c}-.117 * * * \\
(.040)\end{array}$ & $\begin{array}{c}-.103 * * * \\
(.026)\end{array}$ & $\begin{array}{c}-.085^{* *} \\
(.039)\end{array}$ & $\begin{array}{c}-.185 * * * \\
(.062)\end{array}$ & $\begin{array}{l}-.133^{*} \\
(.073)\end{array}$ & $\begin{array}{l}-.096^{*} \\
(.050)\end{array}$ \\
\hline Wage floor change & $\begin{array}{c}-.053 * * * \\
(.014)\end{array}$ & $\begin{array}{c}-.062 * * * \\
(.008)\end{array}$ & $\begin{array}{c}-.034 * * * \\
(.017)\end{array}$ & $\begin{array}{c}-.052 * * * \\
(.019)\end{array}$ & $\begin{array}{l}-.046^{*} \\
(.023)\end{array}$ & $\begin{array}{l}-.041 * \\
(.023)\end{array}$ \\
\hline Inverse Mills' ratio & No & Yes & Yes & No & Yes & Yes \\
\hline Additional controls & No & No & Yes & No & No & Yes \\
\hline Fixed effects & \multicolumn{6}{|c|}{ Industry $\times$ Size, Industry $\times$ Year, Month } \\
\hline
\end{tabular}

Source: Ministry of Labour, Social Security and Welfare, Greek Organization for Mediation and Arbitration (OMED) and ICAP (2006-2016). Authors' calculations.

Notes: Numbers refer to estimates corresponding to the interaction term [Post $\times 5-50$ employees]. In the "Firm-level bargaining" equation, probit marginal effects are reported (Puhani, 2012). Additional controls refer to those reported in Table 5. Standard errors in parentheses are clustered at the firm-level.

*** $\mathrm{p}<0.01, * * \mathrm{p}<0.05, * \mathrm{p}<0.10$ 
Table 7. Differential impact of firm-level bargaining on employment

\begin{tabular}{|c|c|c|c|c|c|}
\hline & [1] & [2] & [3] & [4] & [5] \\
\hline \multicolumn{6}{|c|}{ Treatment: firm-level bargaining (observations: 21,242 , firms: 10,621 ) } \\
\hline \multirow[t]{2}{*}{ Post $\times$ Firm-level contract } & $.111^{* * *}$ & $.112 * * *$ & $.120 * * *$ & $.100 * * *$ & $.085 * * *$ \\
\hline & $(.025)$ & $(.024)$ & $(.027)$ & $(.026)$ & $(.025)$ \\
\hline \multirow[t]{2}{*}{ Post } & .007 & .008 & .138 & .048 & .048 \\
\hline & $(.005)$ & $(.005)$ & $(.120)$ & $(.066)$ & $(.066)$ \\
\hline \multirow[t]{2}{*}{ Firm-level contract } & $.844 * * *$ & $.787 * * *$ & $.787 * * *$ & .004 & $-.015^{* * *}$ \\
\hline & $(.064)$ & $(.059)$ & $(.059)$ & $(.003)$ & $(.005)$ \\
\hline \multirow[t]{2}{*}{ Pre-reform employment } & - & - & - & $.995 * * *$ & $.991 * * *$ \\
\hline & & & & $(.003)$ & $(.003)$ \\
\hline \multirow[t]{2}{*}{ Company Trade Union } & - & - & - & - & $.121 * * *$ \\
\hline & & & & & $(.030)$ \\
\hline \multirow[t]{2}{*}{ Local Trade Union } & - & - & - & - & -.018 \\
\hline & & & & & $(.062)$ \\
\hline Industry & No & Yes & Yes & Yes & Yes \\
\hline Region & No & Yes & Yes & Yes & Yes \\
\hline Post $\times$ Industry, Post $\times$ Region & No & No & Yes & Yes & Yes \\
\hline
\end{tabular}

\footnotetext{
Source: Ministry of Labour, Social Security and Welfare, Greek Organization for Mediation and Arbitration (OMED) and ICAP (2006-2016). Authors' calculations.

Notes: OLS estimates reported. In parentheses, heteroskedasticity corrected standard errors clustered at the firm level. The pre-reform period is 2006-2011 and the post-reform one is 2012-2016. Employment (ln) refers to the period-specific average employment for each firm. Sample consists of firms with a valid number of employees (and firm size with 5 or more employees) observed in both periods.

$* * * \mathrm{p}<0.01, * * \mathrm{p}<0.05, * \mathrm{p}<0.10$
} 